
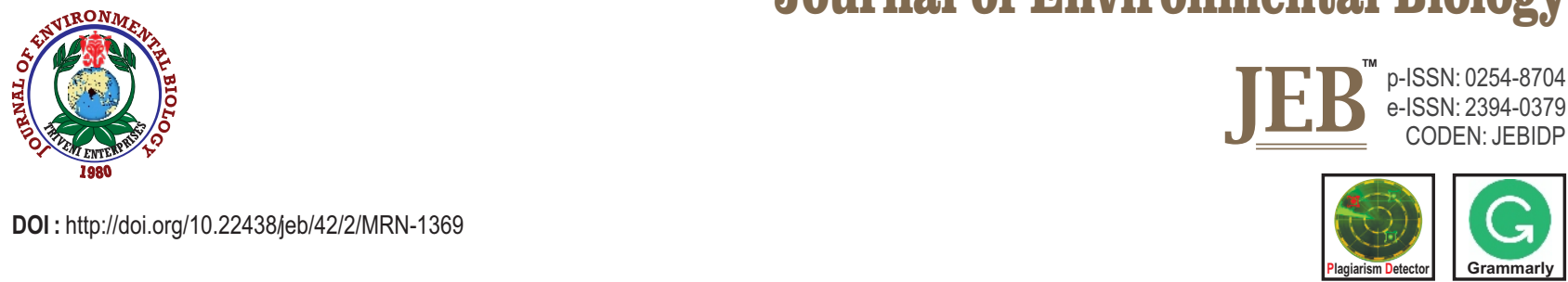

\title{
Optimization of stocking density and feeding ration for rearing of stunted Labeo rohita fingerlings in cages
}

\author{
V.K. Paswan', K.D. Rawat ${ }^{1 *}$, P.P. Srivastava', C. Prakash', M.D. Aklakur', S. Saseendran' and R.S.S. Lingam ${ }^{3}$ \\ ${ }^{1}$ Division of Aquaculture, ICAR - Central Institute of Fisheries Education, Mumbai-400 061, India \\ ${ }^{2}$ CIFE Centre, ICAR - Central Institute of Fisheries Education, Motipur-843 111, India \\ ${ }^{3}$ Krishnagiri-Barur Centre for Sustainable Aquaculture, Dr. J. Jayalalithaa Fisheries University, Krishnagiri-635 201, India \\ *Corresponding Author Email : kiranduber@gmail.com
}

\begin{abstract}
Aim: To rear stunted Labeo rohita fingerlings in cages and determine the optimum stocking density and feeding ration for better growth performance of fishes.

Methodology: Eight-month-old stunted fingerlings of Labeo rohita $(14.65 \mathrm{~cm} / 38.23 \mathrm{~g})$ were stocked in floating net square cages at different stocking densities $\left(10,15,20\right.$ and 25 fishm $\left.^{-2}\right)$ and fed with different feeding ration ( $3 \%, 4 \%, 5 \%$ and $6 \%$ of body weight), further reared for 330 days and fed twice a day with commercial floating pellets with $25 \%$ crude protein. The study followed $4 * 4$ factorial design and were triplicated for each treatment and level.

Results: The study found a decrease in the final body weight, average body weight gain, and specific growth rate with increasing stocking density. The highest final body weight $(732.64 \mathrm{~g})$, body weight gain $(694.30 \mathrm{~g})$ and specific growth rate $\left(0.89 \%\right.$ day $\left.{ }^{-1}\right)$ were recorded in $10 / \mathrm{m}^{2}$ stocking density with feed ration of $6 \%$ body weight. In contrast to this, fish reared in higher stocking density $\left(25 / \mathrm{m}^{2}\right)$ exhibited poor feed conversion ratio. Fish reared in lower stocking density $\left(10 / \mathrm{m}^{2}\right)$ and fed with $6 \%$ feeding ration displayed an enhanced feed conversion ratio, feed efficiency ratio and protein efficiency ratio which indicated that rearing of stunted rohu in intensive cage culture at lower stocking density $\left(10 / \mathrm{m}^{2}\right)$ with higher feeding ration $(6 \%)$ increase their feed utilization capacity.

Interpretation: Rearing of stunted rohu in intensive cage culture is possible, however, the stocking density and feeding ration should be $10 / \mathrm{m}^{2}$ and $6 \%$, respectively, compared to traditional cage practices, in order to reduce stress and to get optimum production.

Optimization of stocking density and feeding ration for rearing of stunted Labeo rohita (Hamilton, 1822) fingerlings in cages.

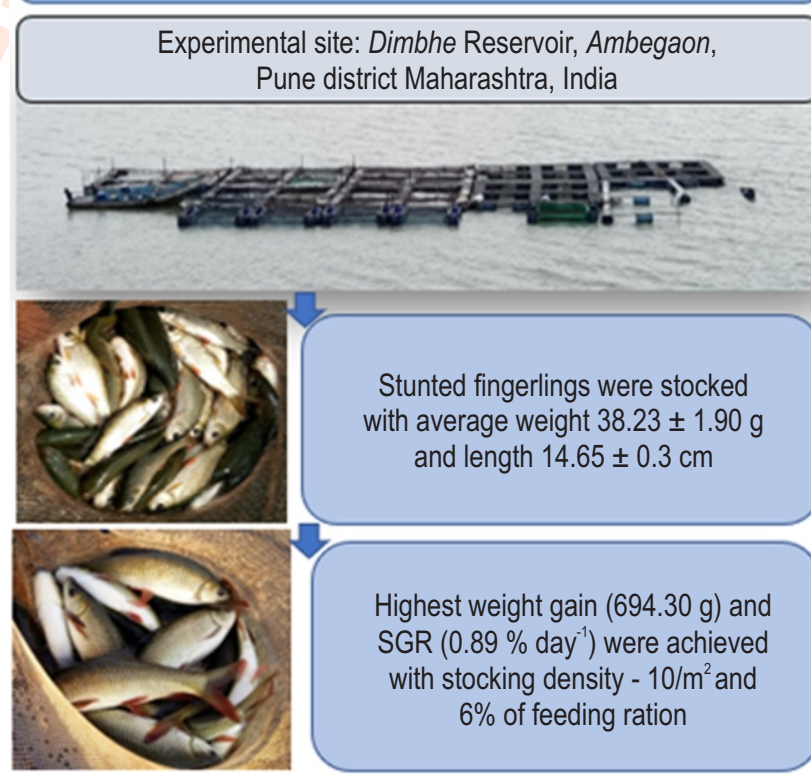

Key words: Cage culture, Feeding ration, Fingerling, Labeo rohita, Stocking density

How to cite : Paswan, V.K., K.D. Rawat, P.P. Srivastava, C. Prakash, M.D. Aklakur, S. Saseendran and R.S.S. Lingam: Optimization of stocking density and feeding ration for rearing of stunted Labeo rohita fingerlings in cages. J. Environ. Biol., 42, 229-234 (2021). 


\section{Introduction}

Reservoirs are man-made impoundments that are constructed by obstructing the surface flow of rivers/streams. It forms an important resource for fish production besides holding up economic growth through various cultural and ecological services. In India, the total area of reservoirs is estimated to be 3.51 million ha (CWC, 2016; Sarkar and Mishal, 2017). Indian reservoirs are recognized as "sleeping giant" for the fisheries development, since the resources are untapped, and it has a huge potential to attain a higher fish yield. Management and intensified culture practices in reservoirs can help to increase the fish production. Cage culture is an intensified way of culturing aquatic organisms in the open water bodies such as reservoirs, open seas, etc. The advantages of cage culture in these water bodies include flexibility in utilizing resources, simplified culture practices and harvesting, and multi-use of water resources (Karnatak and Kumar, 2014).

The growth of cage farming in India got momentum during 2010-2012 with funding support from the National Fisheries Development Board, National Mission on Protein Supplementation, Rashtriya Krishi Vikas Yojna which installed cages in the reservoirs of Jharkhand, Chhattisgarh, Madhya Pradesh, and Maharashtra. At present, there are more than 6000 floating cages made of bamboo, galvanized iron, high density polyethylene installed in inland open water bodies (DAHD, 2018). The main problem in intensive cage culture practice is identification of suitable candidate species. Several researchers have studied the culture possibility of carps in cages by changing the variables such as growth, survival, feed utilization, stocking density, feeding ration, etc., especially using catla (Govind et al., 1988), rohu and common carp (Kohli et al., 2002), Indian major and minor carps (Bhattacharjya et al., 2008), Labeo rohita fry (Biswas et al., 2015) and carp fry (Sarmah, 2017).Generally, healthy carp fry at $12-15 \mathrm{~mm}$ and fingerling of $100-150 \mathrm{~mm}$ are preferred for raising in cages in Indian reservoirs (Das et al., 2004). However, the growth and survival of fish stocked in cages is slow. Therefore, the farmers and institutions are in need of quality seed of carps which can survive and grow well in intensive cage culture practices. The stunted fingerlings or yearlings of Indian Major carps are produced by rearing normal fingerlings at higher stocking densities than usual with sub-optimal level of feeding and fertilization for 8-12 months (Ravi et al., 2012).

This reduces the normal growth of fish and results in stunted seed due to less food availability and overcrowding. When these stunted yearlings are stocked in production ponds, under normal rearing conditions, they show compensatory growth, resulting in faster growth than normal fingerling. The capacity of an animal to grow rapidly after a period of reduced growth is often termed as compensatory growth (Jobling et al., 1994; Jobling and Kaskela, 1996; Melard et al., 1998; Ali et al., 2003; Jobling, 2010). Before starting the commercial level of stunted seed rearing in cages, a right candidate species is to be identified and its optimum stocking density and feeding ration need to be standardized, in order to maximize the production and profitability. Rohu (Labeo rohita) is one of the Indian major carps and is considered as the tastiest among the major carps. It is commonly cultured in the Asian countries, especially in the Indian sub-continent (FAO, 2020). Therefore, this preliminary study was conducted to explicate optimization of stocking density and feeding ration for rearing of stunted rohu in open water cage culture.

\section{Materials and Methods}

Experimental design and rearing of fish: The present study followed a factorial design (4x4) and carried out for 330 days in floating cages installed in a perennial Dimbhe Reservoir, Ambegaon, Pune district Maharashtra, India. Eight-months-old stunted rohu $(14.65 \mathrm{~cm} /$ and $38.23 \pm 1.90 \mathrm{~g})$ were procured from private freshwater fish seed farm, Bharuch district, Gujarat, India. Fish were carefully transported in 1000 I capacity of syntax water tank and oxygen level was maintained at saturation level during transportation using an oxygen cylinder. At experimental site, fishes were disinfected with $\mathrm{KMnO}_{4}$ solution and released into cages for acclimatization for 15 days. Fishes were stocked in 48 cages ( $3 \mathrm{~m} \times 3 \mathrm{~m} \times 3 \mathrm{~m})$ at different stocking densities such as 10, 15, 20 and $25 \mathrm{~m}^{2}$ and fed with different feeding ration such as $3,4,5$ and $6 \%$ of body weight. Stocked fishes were further reared for 330 days and fed commercial floating fish feed (Crude protein 25\%) twice a day in morning ( $9.00 \mathrm{hrs}$ ) and evening (17.00 hrs). The cages were cleaned manually, weekly once, for proper exchange of water to avoid attachment of any barnacles and algae.

Water quality analysis and growth sampling: The water quality parameters of water inside the cages were assessed every month following the standard methods of APHA (2017). Growth sampling was carried out at monthly interval. In each sampling, individual cages were lifted above the water to catch fish. From each cage, 30 fish $(n=30)$ were collected to measure the length and weight. The following fish growth parameters were calculated using the standard formulas.

$$
\text { Weight gain }(\%)=\frac{\text { Final weight-initial weight }}{\text { Initial weight }} \times 100
$$

Feed conversion ratio $=\frac{\text { Feed consumption on dry weight basis }}{\text { Body weight gain on wet weight basis }}$

$$
\begin{aligned}
\text { Protein efficiency ratio } & =\frac{\text { net weight gain on wet weight basis }}{\text { protein fed on dry matter basis }} \\
\text { The survival }(\%) & =\frac{\text { Total fish harvested }}{\text { Total fish stocked }} \times 100
\end{aligned}
$$

Statistical analyses: Statistical analysis of different growth parameters was analyzed by Two-way analysis of variance (ANOVA) using SPSS version 22.0 for windows (SPSS Inc., Chicago, IL, USA). Tukey's range test was used for post hoc comparison of mean values $(P<0.05)$ between different treatment groups. Statistical significance for the test was set at $P<0.05$. 
Table 1: Water quality parameters recorded in cages reared with stunted rohu fingerlings during the experimental period

\begin{tabular}{llll}
\hline Parameters & March - June & July - October & November- February \\
\hline Temperature $\left({ }^{\circ} \mathrm{C}\right)$ & $28-30$ & $23-29$ & $19-24$ \\
Dissolved Oxygen $\left(\mathrm{mg} \mathrm{l}^{-1}\right)$ & $6.3-6.4$ & $7.4-6.8$ & $6.5-7.3$ \\
$\mathrm{pH}$ & $7.4-7.5$ & $7.3-7.5$ & $7.3-7.6$ \\
Total Alkalinity $\left(\mathrm{mg} \mathrm{l}^{-1}\right)$ & $62-78$ & $56-67$ & $36-54$ \\
Total Hardness $\left(\mathrm{mg} \mathrm{l}^{-1}\right)$ & $67-84$ & $58-72$ & $38-58$ \\
Transparency $\left(\mathrm{cm}^{-1}\right.$ & $133-139$ & $100-105$ & $130-135$ \\
Total Suspended Solids $\left(\mathrm{mg} \mathrm{l}^{-1}\right)$ & $0.051-0.054$ & $0.059-0.062$ & $0.052-0.056$ \\
Ammonia-Nitrogen $\left(\mathrm{mg} \mathrm{l}^{-1}\right)$ & $0.28-0.32$ & $0.15-0.23$ & $0.17-0.24$ \\
Nitrite-Nitrogen $\left(\mathrm{mg} \mathrm{l}^{-1}\right)$ & $0.02-0.03$ & $0.01-0.02$ & $0.01-0.02$ \\
Nitrate-Nitrogen $\left(\mathrm{mg} \mathrm{l}^{-1}\right)$ & $0.06-0.09$ & $0.05-0.08$ & $0.05-0.08$ \\
Phosphate $\left(\mathrm{mg} \mathrm{l} \mathrm{I}^{-1}\right)$ & $0.02-0.07$ & $0.01-0.03$ & $0.01-0.05$ \\
Free Carbon dioxide $\left(\mathrm{mg} \mathrm{l}^{-1}\right)$ & Nil & Nil & Nil \\
Biological Oxygen Demand $\left(\mathrm{mg} \mathrm{l}^{-1}\right)$ & $36-64$ & $30-47$ & $35-56$ \\
Chemical Oxygen Demand $\left(\mathrm{mg} \mathrm{l}^{-1}\right)$ & $28-40$ & $26-32$ & $29-38$ \\
\hline
\end{tabular}

\section{Results and Discussion}

The temperature was found to be in the range of 19 to $30^{\circ} \mathrm{C}$ during the experimental trial with highest and lowest values recorded from May-June and November to February, respectively. The range of dissolved oxygen was recorded 6.3 to $7.4 \mathrm{mg} \mathrm{l}^{-1}$ with the minimum level observed during pre-monsoon time (May-June). The $\mathrm{pH}$ values were within the range of 7.3 to 7.6 throughout the experimental period. The total alkalinity during the study was in the range of 36 to $78 \mathrm{mgl}^{-1}$ and the maximum (78 $\mathrm{mgl}^{-1}$ ) and minimum (36 $\mathrm{mgl}^{-1}$ ) values were observed during premonsoon (May-June) and post-monsoon (November-February) periods, respectively. Ammonia was observed from 0.15 to 0.32 $\mathrm{mg} \mathrm{l}^{-1}$ and the highest and lowest values were recorded during monsoon (July-October) and pre-monsoon season (NovemberFebruary). The recorded water quality parameters such as temperature, $\mathrm{pH}$, dissolved oxygen, total alkalinity, ammonia, etc., inside the cages installed in Dimbhe reservoir (Table 1) were within the optimum range for growth and survival of rohu (Labeo rohita) fingerling as reported in previous studies (Banerjee, 1967; Huet, 1972; Bettoli et al., 1985; Boyd and Tucker, 1998; Bhatnagar and Devi, 2013). Furthermore, previous study conducted on this reservoir also reported similar range of water quality parameters which further confirmed conducive environment of this reservoir for rohu cage culture (Mane etal., 2017).

The present trial found significant difference $(P<0.05)$ in the final body weight among the treatments at the end of the experiment (Table 2). The highest final body weight $(732.64 \mathrm{~g})$, weight gain $(694.30 \mathrm{~g})$ and SGR $\left(0.89 \%\right.$ day $\left.^{-1}\right)$ were recorded in fish reared at low stocking density 10 fish $\mathrm{m}^{-2}$ and fed with the highest feeding ration ( $6 \%$ body weight). Fish raised in higher stocking density ( 25 fish $\mathrm{m}^{-2}$ ) and fed with lower feeding ration ( $3 \%$ body weight) exhibited a lower body weight $(211.29 \mathrm{~g})$, body weight gain $(172.96 \mathrm{~g})$ and SGR $\left(0.52 \% \mathrm{day}^{-1}\right)$. The two-way ANOVA analysis clearly showed a significant interaction $(P<$ 0.05 ) between stocking density and feeding ration followed in the present study on final body weight, weight gain and specific growth rate. In the present study, lower stocking density (10 fish $/ \mathrm{m}^{2}$ ) of stunted L. rohita in cages showed better growth performance in terms of higher final body weight, weight gain and specific growth rate which indicates that at lower stocking density stunted fish has better growth potential. On the other side, higher stocking density (25 fish $/ \mathrm{m}^{2}$ ) negatively affected the growth performance of stunted rohu. In general, at higher stocking densities, individual fish gets reduced space which affects the social interaction and increases stress. In stressed condition, fish spends more energy for stress mitigation which reduces the normal growth of fish (Biswas et al., 2015; Ofor and Afia, 2015). Similar growth pattern was reported in catla (Sukumaran et al., 1986; Govind et al., 1988) Labeo rohita (Kohli et al., 2002; Chattopadhyay et al., 2013; Biswas et al., 2015) hybrid catfish (Ofor and Afia, 2015) catla and rohu (Kohli, 2002; Mane et al., 2017).

In fish, the optimal rate of feeding plays a pivotal role which determines the growth potential (Mihelakakis et al., 2002; Cho et al., 2007). The present study found a direct relationship between growth rate and feeding ration which indicated that increased rate of feeding increased the growth performance of stunted rohu. Similarly, stunted rohu and feed restricted Nile tilapia, under optimal feeding conditions, displayed a better growth performance (Das et al., 2008; Limbue and Jumanne, 2014). Stunted fish, in post-stunting phase or optimal feeding condition, exhibited an accelerated body growth as a compensatory growth response (Ali et al., 2003). The reason for faster growth of stunted rohu is increased availability of nutrients which increases the feed consumption and results in better body weight gain. In general, in stunted fish, food availability in poststunting phase profoundly affects the compensatory growth. Similar values were previously reported in tropical fish, Clarias gariepinus (Marimuthu et al., 2011) and Colossoma macropomum (Silva et al., 2007). Therefore, the increased availability of nutrients with the increased feed ration could be the reason for better growth of fish reared in higher feeding ration. 
Table 2: Growth performance, feed utilization and survival of stunted $L$. rohita fingerlings reared in cages under different stocking densities and feeding rations

\begin{tabular}{|c|c|c|c|c|c|c|c|}
\hline $\begin{array}{l}\text { Factors effect } \\
\text { Effect of stocking } \\
\text { density }\end{array}$ & $\begin{array}{l}\text { Final weight } \\
\text { (g) }\end{array}$ & $\begin{array}{l}\text { Weight gain } \\
\text { (g) }\end{array}$ & $\begin{array}{l}\text { Specific growth } \\
\text { rate }\left(\% \text { day }^{-1}\right)\end{array}$ & $\begin{array}{l}\text { Feed conversion } \\
\text { ratio }\end{array}$ & $\begin{array}{l}\text { Feed efficiency } \\
\text { ratio }\end{array}$ & $\begin{array}{l}\text { Protein efficiency } \\
\text { ratio }\end{array}$ & $\begin{array}{l}\text { Survival } \\
(\%)\end{array}$ \\
\hline 10 & $657.85^{\mathrm{a}}$ & $619.54^{\mathrm{a}}$ & $0.86^{\mathrm{a}}$ & $1.73^{d}$ & $0.58^{\mathrm{a}}$ & $2.43^{\mathrm{a}}$ & $100.00^{\mathrm{a}}$ \\
\hline 15 & $349.39^{b}$ & $311.08^{\mathrm{b}}$ & $0.67^{\mathrm{b}}$ & $3.20^{c}$ & $0.31^{b}$ & $1.31^{\mathrm{b}}$ & $98.27^{b}$ \\
\hline 20 & $254.78^{\mathrm{c}}$ & $216.47^{\circ}$ & $0.57^{\circ}$ & $4.59^{b}$ & $0.22^{\circ}$ & $0.93^{\mathrm{c}}$ & $97.87^{\circ}$ \\
\hline 25 & $243.80^{d}$ & $205.49^{d}$ & $0.56^{d}$ & $5.90^{\mathrm{a}}$ & $0.17^{\mathrm{d}}$ & $0.71^{\mathrm{d}}$ & $95.67^{d}$ \\
\hline SEM & 0.68 & 0.69 & 0.001 & 0.04 & 0.003 & 0.01 & 0.07 \\
\hline P-value & 0.00 & 0.00 & 0.00 & 0.00 & 0.00 & 0.00 & 0.00 \\
\hline \multicolumn{8}{|l|}{ Effect of feeding rate } \\
\hline 3 & $310.16^{d}$ & $271.83^{d}$ & $0.61^{d}$ & $3.68^{\mathrm{b}}$ & $0.34^{\mathrm{a}}$ & $1.41^{\mathrm{a}}$ & $97.30^{b}$ \\
\hline 4 & $355.22^{\mathrm{c}}$ & $316.84^{c}$ & $0.65^{\circ}$ & $3.63^{b}$ & $0.34^{\mathrm{a}}$ & $1.40^{\mathrm{a}}$ & $98.29^{\mathrm{a}}$ \\
\hline 5 & $409.19^{b}$ & $370.99^{b}$ & $0.69^{\mathrm{b}}$ & $3.77^{\mathrm{b}}$ & $0.32^{b}$ & $1.35^{\mathrm{b}}$ & $98.10^{\mathrm{a}}$ \\
\hline 6 & $431.26^{\mathrm{a}}$ & $392.92^{\mathrm{a}}$ & $0.71^{\mathrm{a}}$ & $4.33^{\mathrm{a}}$ & $0.29^{\circ}$ & $1.20^{\circ}$ & $98.11^{\mathrm{a}}$ \\
\hline SEM & 0.68 & 0.69 & .001 & 0.04 & 0.003 & 0.01 & 0.07 \\
\hline P-value & 0.00 & 0.00 & 0.00 & 0.00 & 0.00 & 0.00 & 0.00 \\
\hline \multicolumn{8}{|l|}{ Stocking density* } \\
\hline Feeding rate & & & & & & & \\
\hline $10 * 3$ & $548.79^{d}$ & $510.46^{d}$ & $0.81^{\circ}$ & $1.62^{\mathrm{m}}$ & $0.62^{\mathrm{a}}$ & $2.57^{\mathrm{a}}$ & $100.00^{\mathrm{a}}$ \\
\hline $10 * 4$ & $630.78^{\mathrm{c}}$ & $592.39^{\circ}$ & $0.85^{\mathrm{b}}$ & $1.66^{\mathrm{m}}$ & $0.60^{\mathrm{b}}$ & $2.51^{\mathrm{b}}$ & $100.00^{\mathrm{a}}$ \\
\hline $10 * 5$ & $719.20^{b}$ & $681.00^{b}$ & $0.89^{\mathrm{a}}$ & $1.71^{\prime}$ & $0.58^{\circ}$ & $2.43^{c}$ & $100.00^{\mathrm{a}}$ \\
\hline $10^{*} 6$ & $732.64^{\mathrm{a}}$ & $694.30^{\mathrm{a}}$ & $0.89^{\mathrm{a}}$ & $1.91^{k}$ & $0.52^{d}$ & $2.19^{d}$ & $100.00^{\mathrm{a}}$ \\
\hline $15 * 3$ & $268.19^{j}$ & $229.86^{j}$ & $0.59^{h}$ & $3.10^{j}$ & $0.32^{\circ}$ & $1.35^{\circ}$ & $97.28^{\mathrm{c}}$ \\
\hline $15^{\star} 4$ & $312.77^{9}$ & $274.39^{9}$ & $0.64^{\dagger}$ & $3.12^{\mathrm{j}}$ & $0.32^{\mathrm{e}}$ & $1.33^{\dagger}$ & $98.77^{\mathrm{bc}}$ \\
\hline $15^{\star} 5$ & $393.14^{t}$ & $354.94^{t}$ & $0.71^{\mathrm{e}}$ & $3.19^{i}$ & $0.31^{e f}$ & $1.31^{9}$ & $99.26^{\mathrm{ab}}$ \\
\hline $15^{*} 6$ & $423.47^{\circ}$ & $385.13^{\mathrm{e}}$ & $0.73^{d}$ & $3.37^{\mathrm{h}}$ & $0.30^{\dagger}$ & $1.24^{\mathrm{h}}$ & $97.78^{\text {cd }}$ \\
\hline $20 * 3$ & $212.36^{n}$ & $174.03^{n}$ & 0.52 & $4.06^{9}$ & $0.25^{9}$ & $1.03^{i}$ & $98.15^{\mathrm{cd}}$ \\
\hline $20 * 4$ & $244.48^{\prime}$ & $206.09^{\prime}$ & $0.56^{j}$ & $4.04^{9}$ & $0.25^{9}$ & $1.03^{\mathrm{i}}$ & $97.22^{\text {cd }}$ \\
\hline $20 * 5$ & $268.23^{j}$ & $230.03^{i}$ & $0.59^{h}$ & $4.43^{f}$ & $0.23^{h}$ & $0.94^{j}$ & $97.59^{\text {cd }}$ \\
\hline $20 * 6$ & $294.07^{\mathrm{h}}$ & $255.72^{h}$ & $0.62^{9}$ & $5.84^{\circ}$ & $0.17^{\mathrm{j}}$ & $0.72^{k}$ & $98.52^{\circ}$ \\
\hline $25 * 3$ & $211.29^{n}$ & $172.96^{n}$ & 0.52 & $5.93^{b}$ & $0.17^{\mathrm{j}}$ & $0.70^{\prime}$ & $93.78^{\circ}$ \\
\hline $25^{\star} 4$ & $232.86^{\mathrm{m}}$ & $194.48^{\mathrm{m}}$ & $0.55^{\mathrm{k}}$ & $5.69^{\circ}$ & $0.18^{i}$ & $0.73^{k}$ & $97.19^{\text {cd }}$ \\
\hline $25^{\star} 5$ & $256.18^{k}$ & $217.98^{k}$ & $0.58^{i}$ & $5.74^{\mathrm{d}}$ & $0.17^{\mathrm{j}}$ & $0.73^{k}$ & $95.56^{d}$ \\
\hline $25^{\star} 6$ & $274.87^{i}$ & $236.52^{i}$ & $0.60^{\mathrm{h}}$ & $6.22^{\mathrm{a}}$ & $0.16^{\mathrm{j}}$ & $0.67^{\mathrm{m}}$ & $96.15^{\mathrm{cd}}$ \\
\hline SEM & 1.36 & 0.34 & 0.003 & 0.08 & 0.006 & 0.03 & 0.10 \\
\hline P-value & 0.00 & 0.00 & 0.00 & 0.00 & 0.00 & 0.00 & 0.00 \\
\hline
\end{tabular}

Values (mean; $n=30)$ in the column with different superscripts differ significantly $(p<0.05)$. SEM - Standard error of mean

Feed conversion ratio values were found to be lower in low stoking density (1.62) and high in higher stocking density (6.22) with feeding ration of $3 \%$ and $6 \%$, respectively. Significantly higher feed efficiency ratio and protein efficiency ratio values were exhibited by fish raised in lower stocking density fed with different feeding rations, except $6 \%$ feeding ration. Overall, no significant $(P>0.05)$ difference was observed among 3, 4 and 5\% feeding groups. However, significant difference was found among different stocking densities for feed efficiency ratio and protein efficiency ratio values. Statistically, a significant interaction $(P<$ 0.05 ) was found between stocking density and feeding ration.

Feed conversion ratio and feed efficiency ratio are the feed intake parameters used to determine the growth rate and feed utilization capacity of cultured fish (Amin et al., 2005). The feed conversion ratio in the present study showed a direct relationship, i.e., the increase in stocking density and feeding ration increased the feed conversion ratio values. Contrast to this, feed efficiency ratio and protein efficiency ratio values showed inverse relationship, i.e., increase in stocking density and feeding ration decreased the protein efficiency ratio and feed conversion ratio values. The increased feed conversion ratio in higher stocking densities and feeding ration may be due to stress, and the fish might have spent the extracted feed energy for stress mitigation (Liti et al., 2006; Mensah et al., 2013). The result is in agreement with the previous studies conducted in turbot fry (Devesa, 1994; Sahin, 2001). Protein efficiency ratio is used to determine how well the fish had utilized the crude protein present in the diet. In the present study, protein efficiency ratio of fish was negatively affected by increased stocking density and feeding 
ration. The stunted fish reared in lower stocking density (10 fish $\left.\mathrm{m}^{-2}\right)$ exhibited higher protein efficiency ratio probably due to the absence of crowding stress which might have helped them to efficiently utilize protein ( $25 \%$ crude protein) present in the given diet. Similar to stocking density effect, increased feeding ration $(6 \%)$ significantly decreased the protein efficiency ratio value and this may be due to overfeeding of fish where a quantity of feed remains uneaten which increase the value of protein efficiency ratio. Similar observations were reported in tilapia (Essa and Nour, 1988; Cruz and Ridha, 1991) and rohu fry (Biswas et al., 2015). The cent percent survival of fish was observed in low stoking density $\left(10\right.$ fish $\left.\mathrm{m}^{-2}\right)$ and it decreased as the stocking density increased. Significantly lower survival (93.78\%) was recorded in higher stocking density ( 25 fish $\mathrm{m}^{-2}$ ) fed with low feeding ration (3\% of body weight). At lower stocking density and higher feeding rate, the survival percent was found better. In contradictory, higher stocking density did not affect the survival of silver catfish (Kpogue,2013; Tossavi et al., 2016).

However, the present study registered a better survival rate in all treatments which could be due to the fact that stunted seeds are too hardy and survive in stressed condition (Ali et al., 2003). Further more, few studies stated that favorable ecological conditions, also, play a major role in survival of fish in captive conditions (El-Sherif and El-Feky, 2009; Tossavi et al., 2016). Favorable environmental conditions of the study site could be the possible reason for better survival of fish in cages. Hence, Dimbhe reservoir can potentially be used to improve the production of fish through cage culture practices by stocking stunted seed.

The stunted rohu in cages exhibited a better growth performance at lower stocking density and higher feeding ration, therefore, the results suggest that stocking density of 10 fish $\mathrm{m}^{2}$ with a feeding ration of $6 \%$ body weight would be optimum for rearing stunted rohu in cages. From economic point of view, feeding ration of $5 \%$ body weight is cost-effective at 10 fish $\mathrm{m}^{2}$ stocking density.

\section{Acknowledgment}

The authors are thankful to the Director and ViceChancellor, ICAR - Central Institute of Fisheries Education, Mumbai for support and encouragement.

\section{Add-on Information}

Authors' contribution: V.K. Paswan: Carried out the study and prepared the manuscript; K.D. Rawat: Conceptualization of research, guidance and manuscript correction; P.P. Srivastava, M.D. Aklakur: Co-guidance and manuscript correction; C. Prakash: Co-guidance, data analysis, , S. Saseendran: Assisted during sampling; R.S.S. Lingam:Assisted during sampling, data analysis and paper drafting.

Research content: The research content is original and has not been published elsewhere
Ethical approval: NotApplicable

Conflict of interest: The authors declare that there is no conflict of interest.

\section{Data from other sources: NotApplicable}

Consent to publish: All authors agree to publish the paper in Journal of Environmental Biology.

\section{References}

Afzal Khan, M., A.K. Jafri and N.K. Chadha: Growth and body composition of rohu Labeo rohita (Hamilton), fed compound diet: Winter feeding and rearing to marketable size. J. Appl. Ichthyol., 20, 265-270 (2004)

Ali, M., A. Nicieza and R.J. Wootton: Compensatory growth in fishes: A response to growth depression. Fish Fisheries, 4, 147-190 (2003).

APHA: Standard methods of the examination of water and waste water. $23^{\text {rd }}$ Edn., American Public Health Association, Washington, D.C, pp. 1545(2017).

Amin, A.K., M.R. Bapary, M.A. J. Islam, M. Shajahan and M.A.R. Hossain: The impacts of compensatory growth on food intake, growth rate and efficiency of feed utilization in Thai pangas (Pangasius hypophthalmus). Pak. J. Biol. Sci., 8, 766-770 (2005).

Apines-Amar, M.J.S., R.M. Coloso, M. Amar, G. Novie, M. Golez, M. Shirley, M.G.B. Bunda and C.J. Jaspe: Utilization of mung bean, Vigna radiata (Linnaeus) as a novel protein source in practical-type diets for juvenile milkfish, Chanos chanos (Forsskal): Effects on growth, feed efficiency, body composition, and histology of gut and liver. Isr. J. Aquacult. Bamid., 67, 1-10 (2015).

Banerjea, S.M.: Water quality and soil condition of fish ponds in some states of India in relation to fish production. Indian J. Fish, 14, 115144 (1967).

Bettoli, P.W., W.H. Neill and S.W. Kelsch: Temperature preference and heat resistance of grass carp Ctenopharyngodon idella (Valenciennes), bighead carp, Hypophthalmichthys nobilis (Gray) and their F1 hybrid. J. Fish Biol., 27, 239-247 (1985).

Bhatnagar, A. and P. Devi: Water quality guidelines for the management of pond fish culture. Int. J. Environ., 3, 1980 (2013).

Bhattacharjya, B.K., R.K. Manna, K.K. Sarma and A. Biswas: Growth performance of Indian major and minor carps in cage aquaculture for raising stocking materials in Puthimari beel, Assam. J. Inland Fish Soc. India, 40, 93-98 (2008).

Biswas, P., M.P. S. Kohli, N.K. Chadha, B.K. Bhattacharjya, D. Debnath, S. Yengkokpam, K.K. Sarma, P. Gogoi, A. Kakati and A.P. Sharma: Optimizing stocking density of Labeo rohita fry in cage aquaculture system as a tool for flood plain wetland fisheries management. $J$. Biol. Sci., 85, 181-190 (2015).

Boyd, C. E. and C. S. Tucker: Pond aquaculture water quality management. Kluwer Academic Publishers, Boston, pp. 700 (1998).

Chang, W.Y.B.: Fish production: Data synthesis and model development. Pond Dynamics/Aquaculture Collaborative Research Support Program. $6^{\text {th }}$ Annual Administrative Report, Oregon State University, Oregon., USA, pp. 41-49 (1988).

Chattopadhyay, D.N., B.C. Mohapatra, S. Adhikari, K.C. Pani, J.K. Jena and A.E. Eknath: Effects of stocking density of Labeo rohita on survival, growth and production in cages. Aquacul. Int., 21,19-29 (2013).

Cho, S.H., S.M. Lee, B.H. Park, S.C. Ji, C.Y. Choi, J.H. Lee, Y.C. Kim, 
J.H. Lee and S.Y. Oh: Effect of daily feeding ratio on growth and body composition of sub adult olive flounder (Paralichthys olivaceus) fed an extruded diet during the summer season. J. World Aquacult. Soc., 38, 68-73 (2007).

Cruz, E.M. and M. Ridha: Production of the tilapia Oreochromis spilurus Gulnther stocked at different densities in sea cages. Aquaculture, 99, 95-103 (1991).

CWC: National registers of large dam's Central water commission. Basic Animal Husbandry and Fisheries Statistics, New Delhi: Department of Animal Husbandry, Dairying and Fisheries, Ministry of Agriculture and Farmers Welfare, Government of India (2016).

DAHD: Annual Report. Department of Animal Husbandry, Dairying and Fisheries, Govt. of India, p. 192 (2018).

Das, A. K., N.P. Shrivastava, K.K. Vass and B.L. Pandey: Management strategies for enhancing fish production in Madhya Pradesh reservoirs. In proceedings of Taal 2007: The $12^{\text {th }}$ World Lake Conference, (1295) 1300 (2008).

Debnath, D., S. Yengkokpam, B.K. Bhattacharjya, P. Biswas, C. Prakash, M.P.S. Kohli and A.P. Sharma: Effect of dietary incorporation of drypowdered water hyacinth (Eichhornia crassipes) meal on growth and digestibility of Labeo rohita fingerlings. Springer India, In: Proc. Zool. Soc. Lond., 71, 74-82 (2018).

Devesa, S.: Nutrition and feeding of cultured turbot (Scophthalmus maximus). European Aquaculture Society Special Publication (Belgium) (1994).

El-Sherif, M.S. and A.M.I. El-Feky: Performance of Nile tilapia (Oreochromis niloticus) fingerlings II, Influence of different water temperatures. Int. J. Agric. Biol.,11, 1814-9596 (1994) (2009).

El-Sherif, M.S. and A.M.I. El-Feky: Effect of pH on growth performance of Nile tilapia (Oreochromis niloticus) fingerlings. Int. J. Agric. Biol., 11, 297-300 (2009)

Essa, M.A. and A.M. Nour: Effect of stocking density and supplementary feeding on growth rate food utilization and cost of tilapia hybrid production (Oreochromis niloticus $X 0$. aureus) in cages. In: Proceedings oflst Conference on Development of Fisheries Research, Alexandria, Egypt, pp. 6-8 (1988).

Govind, B.V., S. Ayyappan, S.L. Raghavan and M.F. Rahman: Culture of catla (Catla catla) in floating net cages. Mysore. J. Agric. Sci., 22, 517-522 (1988).

Huet, M. and J.A. Timmermans: Textbook of fish culture. Breeding and cultivation of fish (No. Ed. 2). Fishing News Books Ltd. (1986).

Jobling, M.: Are compensatory growth and catch-up growth two sides of the same coin?. Aquac. Int., 18, 501-510(2010).

Jobling, M. and J. Koskela: Interindividual variation in feeding and growth in rainbow trout during restricted feeding and in a subsequent period of compensatory growth. J. Fish Biol., 49, 658-667(1996).

Jobling, M., O.H. Meloy, J.D. Santos and B. Christiansen: The compensatory growth response of the Atlantic cod: Effects of nutritional history. Aquac. Int., 2, 75-90 (1994).

Karnatak, G. and V. Kumar: Potential of cage aquaculture in Indian reservoirs. Int. J. Fish. Aquat. Stud., 1, 108-112 (2014)

Khan, R. and Q. Siddiqui: Studies on the age and growth of rohu, Labeo rohita (HAM) from a pond (MOAT) and rivers Ganga and Yamuna. Proc. Indian Natl. Sci. Acad., 39, 582-597 (1973).

Kohli, M.P.S., S. Ayyappan, R.K. Langer, K. Dube, C. Prakash, A.K. Reddy and G. Deshmukhe: Cage culture of carps, Labeo rohita and Cyprinus carpio at Powai lake, Mumbai, Maharashtra. Appl. FishAquac., 2,1-4 (2002)

Kpogue, D., H. Gangbazo and E.A. Fiogbe: Preliminary study on the dietary protein requirement of Parachanna obscura (Günther,
1861) larvae. Turk. J. Fish Aquat. Sci., 13, 111-117 (2013).

Liti, D.M., R.M. Mugo, J.M. Munguti and H. Waidbacher: Growth and economic performance of Nile tilapia (Oreochromis niloticus) fed on three brans (maize, wheat and rice) in fertilized ponds. Aquac. Nutr., 12, 239-245 (2006).

Mane, A. M., K. Dube, T. Varghese, B. R. ChavanandM. T. Kamble: Effects of stocking density on growth performance, survival and production of Catla catla and Labeorohita during nursery rearing in cages. Proc. Natl. Acad. Sci. India Sect. B. Biol. Sci., 89, 275-281 (2017).

Mane, A.M., D. Meena, T. Varghese, K. Syamala and A.P. Muralidhar: Effect of stocking density on the growth, survival and yield of carp fry reared in pens. Int. J. Curr. Microbiol. App. Sci., 6, 641-648 (2017).

Marimuthu, K., R. Umah, S. Muralikrishnan, R. Xavier and S. Kathiresan: Effect of different feed application rate on growth, survival and cannibalism of African catfish, Clarias gariepinus fingerlings. Emir J. FoodAgr., 330-337 (2011).

Mensah, E.T.D., F.K. Attipoe and M. Ashun-Johnson: Effect of different stocking densities on growth performance and profitability of Oreochromis niloticus fry reared in hapain- pond system. Int. J. FishAquac., 5, 204-209 (2013).

Mihelakakis, A., C. Tsolkas and T. Yoshimatsu: Optimization of feeding rate for hatchery produced juvenile gilthead sea bream, Sparus aurata. J. WorldAquacul. Soc., 33, 169-175 (2002).

Melard, C., E. Baras and D. Desorez: Compensatory growth of nile tilapia, Oreochromis niloticus. J. World Aquacul. Soc., 29, 87-95(1998).

Ofor, C.O. and O.E. Afia: Effect of stocking densities on growth and feed utilization of hybrid catfish (Clarias gariepinus $X$ Heterobranchus longifilis) fed at $1 \%$ body weight. Am. J. Biomed. Sci., 3, 211-217 (2015).

Ravi, C., S. Padinhate purayil, S. Razvi, V. Gundaboina and A. Anirudhan: Lower size at maturation reduces somatic yield in pond reared stunted yearlings of rohu, Labeo rohita (Hamilton). Indian J. Fish, 59, 171-174 (2012).

Sahin, T.: Larval rearing of the Black Sea turbot (Scophthalmus maximus) (Linnaeus, 1758), under laboratory conditions. Turk. J. Zool., 25, 447-452 (2001).

Sarkar, U.K., K.M. Sandhya, P. Mishal, G. Karnatak, Lianthuamluaia, S. Kumari, P. Panikkar, R. Palaniswamy, M. Karthikeyan, S.S. Mol and T.T. Paul: Status, prospects, threats, and the way forward for sustainable management and enhancement of the Tropical Indian Reservoir Fisheries: An overview. Rev. Fish Sci., 26, 155-175 (2018).

Sarmah, A., S. Bora, R. Bania and S. P. Biswas: Cage culture of carps in Ox-Bow Lakes of Assam: A case study. Oceanograph. Fish., 1, 1-4 (2017).

Silva, C.R., L.C. Gomes and F.R. Brandão: Effect of feeding rate and frequency on tambaqui (Colossoma macropomum) growth, production and feeding costs during the first growth phase in cages. Aquaculture, 264, 135-139 (2007).

Sukumaran, P.K., S.L. Raghavan, M.F. Rahaman, S. Ayyappan and S. Parameswaran: December cage culture of the carp, Catla catla (Hamilton) in a freshwater tank in Bangalore. In: Proceedings of National Symposium on Fish and their Environment, Hardwar, India., pp. 15-18 (1986).

Tossavi, C.E., A.S.M. Djissou, N.I. Ouattara and E.D. Fiogbe: First breeding experiments of an African Siluriforme: Transfer and storage of Schilbe intermedius (Rüppell, 1832). Int. J. Innov. Appl. Stud.,17, 487-495 (2016). 